\title{
Understanding Children, \\ Communicating With Children: \\ Approaches to the Child Within Us, \\ Before Us, and With Us
}

\section{Wilfried Lippitz}

Universität Gesamthochschule, Siegen, West Germany

As long as we see the actions of little children through the models of our shared adult conventionality, we are not likely to see the world as children, in their own uniqueness, see it. (Beekman, 1983, p. 40)

How are we adults able to understand our children adequately, how they perceive the world, which problems they have with themselves and with us adults, how they come to terms with the tasks and demands we set them, and so forth?

\section{The Child Within Us as a Way to the Child Before Us}

Is it possible for us to adopt the perspective of children simply through understanding our own selves, by imaginatively reconstructing our own childhood? This approach has a number of basic difficulties. The child who appears in the reminiscences of the adult and who he once was, is and remains the remembered child, and as such is bound inextricably to the perspective of the person remembering in the present. Due to the coherence of time the structure of which Merleau-Ponty called "transitional synthesis," the binding of past and future in the presence field of present (Merleau-Ponty, 1966, p. 416), our past is conveyed via the present. Nevertheless, our original childhood remains lost to us forever. We are not the child we remember; our past does not enter into the present of the one who remembers as the original presence but as the past mediated by the momentary present. It is the child of the remembering adult, therefore, to a certain extent, a different child from the original. It takes the same road to adulthood and treads the same tortuous paths of education on which it will not remain what it once was. The state of affairs is paradoxical: That which was originally and directly familiar to us, in other words the child as we existed, becomes, in a specific way, foreign to us.

This is how Christa Wolf sees it at the beginning of her autobiography Kindheitsmuster (Structures of Childhood, 1985). There she describes the difficulties she experienced when attempting to recall her own childhood. Could she say "I" to the child she was remembering? 
Because it is hard to admit that that child there-three years old, defenceless, alone-is out of your reach. Not only are you separated from it by forty years, not only are you hindered by the unreliability of your memory, which works according to the principle of island (Inselprinzip) and whose instructions are: Forgot! Falsify! After all the child has also been left by you. First of all by the others, okay. But then also by the adult who emerged from it and after a while managed to do everything to it that adults tend to do to children: He left it behind, shoved it aside, forgot it, pushed it away, disowned it, refashioned it, falsified it, and neglected it, felt ashamed of it and boasted of it, loved it wrongly and hated it wrongly. Now because it is impossible, he wants to get to know it.

(Wolf, 1985, p. 12)

That looks sinister: this image of a child who falls prey to the adult. It is drawn into the lifelong process of interpreting oneself and the world which is typical of mankind. Far from making his own story, the adult is constantly involved in stories which turns his efforts to create an identity into a constant search for it. They are just incapable of coming to a conclusion as the experiences which one comes up against. Their horizons point to the future and the past and, as such, remain unattainable. They lead the self to be influenced by social and historical events which it can only assimilate as particles because it remains situated within them (Buck, 1981, p. 123). The self is not the subject of its stories. It finds itself within them and relates to them in a more or less active or passive manner. Consequently the child who I have been became drawn into the mass of identification processes. In Christa Wolf's eyes, these processes are everything but harmoniously forming self-conceptions or self-projections which peacefully build upon each other (Wolf, 1985).

On the contrary, they are sorrowful, contradictory processes which are involved with the material they draw on. The child I once was becomes, so it seems, recreated again and again in such attempts at self-understanding. Am I then completely cut off from my past? Does the child I once was become dissolved in the respective present interpretations, and would it be simply the product of projections of the present? If this were the case we would be trapped in the stages of our life. There would be no memory which would make the stages permeable to each other. Would the adult be incomprehensible for the child and necessarily subject it to the adults' perspective? Or must not the child be right with regard to the adult?

It is therefore impossible, as Christa Wolf suggests, for me to find the way back in my memory to the child I once was. Has the child become a complete stranger to me as the result of my self-alienation? Christa Wolf answers in a positive way: She writes her autobiography. Her massive doubts regarding the possibility of doing so appear to point to the initial difficulties of making a start. These 
doubts do not disappear entirely in the process of writing; they are weakened. I would like to examine a fundamental condition of the possibility of autobiographical reconstruction more closely.

The author draws attention to herself. As the subject, I have little access to my stories, and just as little do I have arbitrary access to my memory. I do not invent my past, nor am I able to recall it as often as I like, in the way I like, or at the time and place I desire. In other words, these are not merely the plaything of subjectively arbitrary attempts at interpretation like my experiences, which do not come about merely in my head, but which require my physical involvement in the world. My memories need a material and social support so that they do not remain just products of the mind. Christa Wolf returns to the places where she spent her childhood. The still familiar things she finds there and the things she does not find there, but misses, activate her memory. Yes, one could even say it surprises her with memories which she had long considered lost. With the aid of a still present world, which at the same time refers to an already past world and brings it into the presence of memory, the past is condensed. It hecomes an image of childhood, composed of a complex fabric of scenes, bits of memories (familiar furniture, secret playing areas, long since yellowed or burned photos, etc.), and dream visions. Far from being merely a web of momentary imagination, it is nevertheless not so concrete that it could not be attached by doubts regarding its genuineness which arise in the person remembering. Because, as Christa Wolf says, there does not exist an "outside witness who has passed on so many of our memories of early childhood which we consider genuine" (p. 11).

Can we rediscover the child we once were? There is an answer which is, however, by no means definitively positive or negative but which, in a remarkable way, remains in suspense. The remembered child is not exclusively the product of a memory which enters the consciousness of the biographical self. Nor is the memory a sort of store in which all past experiences are kept and made available to a selftransparent self-consciousness. Self-transparency would mean putting time completely out of action. It would be senseless to even talk of distinguishable time modalities. The remembered child as a stored child would simultaneously be the present child. The adult, if one can speak of him at all, would differ from the child solely through the greater storage capacity with a greater storage quantity. Only when the memory is more than what we already know, when it surprises us with memories we have not had before, when it connects with experiences by transcending the sphere of consciousness and is tied to the sensually and physically experienced world, only then can the child exist who once had been. Not created in the present but motivated by present experiences, occurrences, or events (and for this one needs merely a strong scent or the atmosphere of a place 
which reminds one of certain childhood memories), this child enters the presence of the adult, often surprisingly and provocatively vividly. That which is amalgamated with the present in this way is part of its open experience. Therefore, my childhood is never a closed chapter of the story of my development.

Here we are subject to the structural principles of hermeneutic experience, which has systematized the concept of truth and tied it to history. The question, whether I will ever reach the child I once was with my interpretations, becomes meaningless. To do that, I would have to be in a position to put out of action the person I have become, that is, my historical being, and to transform myself into what Merleau-Ponty would call a consciousness glancing over space and time (1966). Only then would I achieve the truth without gaps and differences. Then I would also need to tell $m y$ story in the constant attempt to acquire my biography, both reflectively and at the same time communicatively with the helps of others. The distance in time is a productive quality (Gadamer, 1960, p. 275). Applied to our problem this means: Just because $I$ am an adult, $I$ am able to understand the child I once was. As adults we know, in a certain respect, more about the child we once were, who in those days was numbed by the pathic dialect of the world, and hardly had reason to place himself or herself in a reflective relationship to the world or to himself or herself. For example, we now know the historical and social constellations of living conditions in those days, which perhaps influenced the life of the family; also the knowledge of psychoanalytic theory can throw light on our family relationships in those days. Therefore, every attempted autobiographical interpretation is not simply the doubling of one's own childhood, but rather, a history of forming (Bildung) in the active sense of the word and in the inevitably retrospective manner of narrative history.

An autobiographical interpretation is forming because that which is remembered, that which is often present in the form of fragmentary and unconnected scenes, is subsequently incorporated into the framework of a story which must have a beginning, a line of development, and an end-no matter how fictitious this teleological organization of the course of my life is. This sense of a temporary end to my life story may be as a result of a certain development to which the course of my life is subjected. Viewed retrospectively, we are, to a certain extent, ahead of our past (Sartre, 1983, p. 116). An autobiographical interpretation is forming also for the reason that, apart from these formal principles of education, thematic principles play a crucial role. Certain scenes of childhood prove themselves retrospectively to be key scenes. They have perhaps had far-reaching effects until now or, in a remarkable way, they remain in a strange manner ruins within the memory which resist any attempt at categorization or interpretation. 
But does not this coming to terms with one's childhood through the application of knowledge and theory remain somehow usurping in respect to it, perhaps even violent, especially when we are not satisfied with understanding our childhood better, but make autobiographical material the subject of systematic research? Does not the unmistakably unique and particular become transformed into special instances of a given general rule? Is not the particular aura of the authentic, close-to-life, and visibly concrete which surrounds the (auto)biography lost in the process? With this aura, the pedagogical biography research hopes to achieve a more sensitive pedagogical consciousness of complex educational relationships (Baacke, 1979 , p. 25). Or to express it in terms of contemporary issues: Does not the region of present time, which assures me of my past as a former present belonging to me, become abolished in favor of a theoretical context of explanation? This would remain reserved in respect to the lived and experienced time and would situate itself in the context of the "generalized time" of the scientific community. If, for example, one were to believe the claims of "objective hermeneutics" (Oevermann, 1980), then such a scientific community would not be simply the witness, of which Christa Wolf spoke, who accompanied me in my childhood and would therefore be in a position to certify for me the genuineness of my memories. More than that-my memories would be guided by a theoretically conducted scientific discourse as if through a filter. They would be the material which would be examined for basic depth structures, for structures which have a universal character in the general process of socialization, and, therefore, regard me as one case among other cases. As in the experimental, mostly psychological, research of children, there is a great danger here also that the perspective of the adult dominates that of the child; that here, as well as there, the theoretical constructions begin to lead a life of their own at the expense of individuality and applicability (compare, e.g., Meyer-Drawe, 1986; Spiecker \& Groenendijk, 1985).

Unfortunately, this problem is not confined to the area of science. Because, if the theoretical constructions become components of the practiced knowledge of educators, then they tend to creep into concrete pedagogical practice and cause confusion there. The consequences could resemble those which von Hentig (1977) noted in reference to teacher education: Science is often learned during training as the fixed knowledge of theories and methods, without consideration of how they arose in real-life conditions and how they affected these conditions. Scientific theorems would then, in the minds of the students, coagulate into the stereotypes "of the socioeconomic determinants, of restricted and elaborated code, of performance and competence, role-taking, role-distance, roleexpectation, role-conflict, of cognitive, affective, and (subsequently 
acquired) social learning, of deviance and norm-oriented behavior" (p. 173). They would acquire the character of "Aristotelian substances" and would often enough obstruct the pedagogical intention which is geared to finding practical solutions. This form of knowledge would thus hinder the ability to have experiences. On the other hand, experiences which did comply with the theoretical framework would remain peculiarly speechless, although the concrete problem could be expressed within them. For our context this would mean that dealing with biographies, despite the closeness to "lived life," could not guarantee that even the knowledge one extracts from them with the help of analyses would remain alive.

This means that, for the sake of its practical pedagogical relevance, biographical research must keep the forming of theories in check. Biographies must not be allowed to degenerate into the supplies of material which aim to satisfy preconceived theoretical notions. One can learn from the concrete and particular (compare Lippitz, 1980, 1983, 1984; and recently Binneberg, 1985). In everyday human intercourse, not only does the determining power of judgment act, which reduces the particular to an example of a given universal, it is also true that the reflective power of judgment is sensitive to the particular (Buck, 1969, p. 97). The universal activity within it can be traced (and at the same time, without removing it from its context entirely) and made amenable to the intersubjective test. In this way every concrete pedagogical practice, and also every biography, attains an exemplary character because it may potentially instruct me. From the biographies of others, I learn by trying to make them comprehensible to me. At the same time, they disclose my own history to me, which otherwise may have remained in the dark without the help of the others. So my biography or the biography of an other person helps me, in a certain way, to find myself.

\section{The Child With Us as a Way to the Child Before Us?}

Let us now change the perspective. What is the situation, with the recommendation of the pedagogical research in this area, that we should go among the children if we want to find out what they are like (compare Beekman, 1984; Bleeker \& Mulderij, 1984) Let us take up the opening quotation from Beekman again and continue it:

As long as we see the actions of little children through the models of our shared adult conventionality, we are not likely to see the world as children, in their own uniqueness, see it ... With my adult goal orientation, I am frequently not "here" where I really am. Going to the School of Education I sometimes mentally project in time to the seminar about to take place. What I don't see is that the painters have altered the roof and painted the walls of the corridor. But Sasha, a 3-year-old, told me. He is not hindered by adult projections "far away" into the future. Conventional meanings hinder what we see, whereas the child's landscape is more immediate and more exciting-full of colors and changes which I, as an adult, don't notice. (Beekman, 1984, p. 40) 
This small example from Beekman shows that just being together with children is enough to shake the prejudices of the adult and his or her everyday routine habits of perception and behavior, provided that the adult is open-minded and sensitive enough. The usual labeling of childish behavior as childish concretism in developmental psychology, which could perhaps be applied to Sasha here, would fix the adult's advantage over the child in rationality too quickly and in too simplified a form. But is the adult more rational in his behavior when he walks about the place not seeing what changes are happening because his mind is somewhere else? This "multilocality" (Waldenfels, 1986, p. 206), this ability to be somewhere else in one's wishes and ideas from the place where one actually is at the time, is surely an expanded and not purely negative means of experiencing one's environment. The positive function of the human imagination, which can appear for example in the form of daydreams, has been stressed by Bloch (1973, p. 80). It is an important potential for the development of "concrete utopias," which is required for the changing of existing circumstances-provided however that it simultaneously keeps a watchful eye on the present itself in which something should be changed and which constantly changes. If both things are of any value (the so-called concretism with its closeness to perceived reality and with its sensitiveness to concrete changes in it, and the multilocality with its anticipatory power), then it is not possible to determine once and for all which form of behavior is to be regarded as more rational and more developed. In our context, the child's view of the world must claim its right when compared with the adult's view of the world.

Apart from this more episodic experience with children which Beekman introduces us to, there is the systematized experience of the research work in this field which follows a certain research program. Often the researcher enters the field as an outsider, but with a concept at variance with the traditional empirical-analytical research, namely of becoming familiar with the field by developing his or her research interests and instruments in the field, and with the help of those who are active there. But how does one become familiar with the field, for example, with children as the subjects of one's research? How do I enter into the field in such a way that I do not increase my original outsider quality by applying inappropriate categories and models of interpretation to my research activity? The entry into the field is regarded unanimously by many authors as the crucial factor for successful or unsuccessful research (compare, among others, Mulderij: Wie is er bang voor kinderen?-Over participerende observatie, in Bleeker \& Mulderij, 1984, p. 79).

Let us clarify this problem with an example given to us by Coenen (1984, p. 39; compare also Lippitz, 1983, p. 53). In his field work, Coenen was concerned with structures of communication and inter- 
action between deaf mute children in an American school for the deaf, and with the possibilities of integrating these handicapped children into a normal school. In two respects, the researcher was an outsider here, that is, the area of research was unfamiliar to him: The children and the school were unknown to him and the children presented him with a particular comprehension problem because they were handicapped-a problem which he was unable to solve with the usual means of communication he was familiar with. At the same time, the inexperienced and nonhandicapped outsider presented the children with a comprehension problem if they were to have dealings with him and were not to refuse him entry into the field. Just as the researcher had to be able to learn, because he would make no progress with verbal behavioral habits which dominate in everyday intercourse, so the children also had to learn anew. Precisely in this situation do the structures of communication and interaction which are to be examined become thematic.

How did Coenen obtain entry to the field? He himself reports:

During my battle with depression and tiredness, [I] stubbornly excited myself to remain seated and at any price to scribble something in my notebook, I did not notice what really helped me out of this situation. More than a year later, when the set goal of establishing results had been achieved to a certain extent, I went back over those first awkward, fragmentary notes. Suddenly it dawned on me: The children themselves did it. It was not I, myself, who had forced the way, but they, who at small unnoticeable moments integrated me.

How did they manage it? In my opinion there is one single term for it: That of "incorporation," for they drew me "with their bodies" into their world. At first it was the glances. Often I noticed these open, friendly, curious faces turned toward me, giving me the impression: "Here you are immersed in what we are doing here, what exactly is the role you are playing?" (1984, p. 42)

After a time, the researcher then took on the function of providing extra help during lessons, played with the children, and even acquired a little of the sign language.

With this example we learned that the researcher is not put into a position to research until he is a learner and participant. Before he understands something, he must know it well. That means he must acquire the competence to deal with the children practically, and as we know, this competence can only be acquired through dealing with people and not before, just as one learns a language by speaking it and not by learning its grammar and vocabulary. Belonging to the field of research as a basis for understanding is, however, not assured for the researcher from the very beginning through everyday knowledge or through behavioral conventions. They are not available to him from the beginning as a more or less unquestionable 
reservoir of interpretation. And so an important assumption (which is usually regarded in qualitative social research as a given entity) has become problematical. Rather, there are the children who, in a more implicit, prelinguistic manner, and with the help of the syncrete interconnection of bodies, of the functioning intercorporality (Meyer-Drawe, 1984) between researcher and the subjects of field work, are involved in the opening up of the field for the researcher. The so-called epistemological subject of research changes here considerably in comparison with its traditional form: $\mathrm{He}$ or she leaves the central position in the research process (decentralization), receives a biographical and, at the same time, precognitive dimension (physical, social, and historical location), and does not achieve his or her competence until during the research process itself (learning dimension). In a literal sense, he or she is not master of the situation. He or she can only understand what is happening in the field and within himself or herself, if he or she allows himself or herself to be drawn into the process of communication with the children by the children.

In this case, therefore, the communication precedes the understanding. Our example clearly illustrates the socioethical dimension of field research. The researcher expects of the children that they be ready to admit him or her into their world. At the same time, they require that he or she becomes aware of their demands. This mutual obligation to accept one another's strangeness is the necessary, but not sufficient, condition with which communication, and through it understanding - as a living sensual-physical process-becomes possible. That this process is set in motion cannot be planned by the researcher in advance. It can, as Coenen shows, take place so to speak, behind the researcher's back.

It becomes obvious here, as well, that the way to the children before us does not stop in front of them. The researcher's view from a distance is inadequate for us. On the contrary, the closeness of them which they allow us, the participation in their life, makes our understanding possible.

\section{References}

Baacke, D. 1979. Ausschnitt und Ganzes-Theoretische and methodologische Probleme bei der Erschliessung von Geschichten. In Ders./Schulze Th., Aus Geschichten lernen. Zur Einübung pädagogischen Verstehens (pp. 11-50). München: Iuventa.

Beekman, T. (1983). Human science as a dialogue with children. Phenomenology + Pedagogy, 1(1), 36-44.

Beekman, T. (1984). Hand in Hand mit Sasha: uber Glühwürmchen, Grandma Millie und andere Raumgeschichten. In W. Lippitz \& K. Meyer-Drawe (Eds.), Kind und Welt. Phänomenologische Studien zur Pädagogik (pp. 11-26). Königstein/Ts: Hain. 
Binneberg, K. (1985). Grundlagen der pädagogischen Kasuistik. Uberlegungen zur Logik der kasuistischen Forschung. Zeitschrift für Pädagogik, 31(6), 773-778.

Bleeker, H., \& Mulderij, K. (1984). Pedagogiek op je knieen. Aspecten van kwalitatief-pedagogisch onderzoek. Meppel: Boom.

Bloch, E. (1973). Das Prinzip Hoffnung (1. Bd.). Frankfurt/M: Suhrkamp.

Buck, G. (1969). Lernen und Erfahrung. 2. Aufl. Stuttgart: Kohlhammer.

Buck, G. (1981). Hermeneutik und Bildung. München: Wilhelm Fink.

Coenen, H. (1984). Improvisierte Kontexte: Bewegung und Wahrnehmung in Interaktion tauber Kinder. In W. Lippitz \& K. Meyer-Drawe (Eds.), Kind und Welt, pp. 39-62. Königstein/Ts: Hain.

Gadamer, H.G. (1960). Wahrheit und Methode. 2. Aufl. Tübingen: J.C.B. Mohr.

Lippitz, W. (1980). Lebenswelt oder die Rehabilitierung vorwissenschaftlicher Erfahrung. Weinheim, Basel: Beltz.

Lippitz, W. (1983). Das Allgemeine durch das Besondere. Lebensweltliche Forschung als biographisch gestützter Lernprozess. Pedagogische Verhandelingen. Tijdschrift voor wijsgerige en historische pedagogiek, 6(1) 53-61.

Lippitz, W. (1984). The child's understanding of time. Phenomenology + Pedagogy, 1(2), 172-180.

Merleau-Ponty, M. (1966). Phänomenologie der Wahrnehmung. Berlin: De Gruyter.

Meyer-Drawe, K. (1984). Leiblichkeit und Sozialität. Phänomenologische Beiträge zu einer pädagogischen Theorie der Intersubjektivität. München: Wilhelm Fink.

Meyer-Drawe, K. (1986). Zähmung eines wilden Denkens? Piaget und Merleau-Ponty zur Entwicklung der Rationalität. In A. Metraux \& B. Waldenfels (Eds.), Leibhaftige Vernunft. Spuren von Merleau-Pontys Denken (pp. 258-275). München: Wilhelm Fink.

Oevermann, U.A. (1980). Zur Logik der Interpretation von Interviewtexten. In U.A. Th. Heinze (Eds.), Interpretationen einer Bildungsgeschichte. Uberlegungen zur sozialwissen-schaftlichen Hermeneutik (pp. 15-69). Bensheim: Päd. extra.

Sartre, J.-P. (1983). Die Wörter. Reinbek: Rohwolt.

Spiecker, B., \& Groenendijk, L.F. (1985). Betrogene Kinder? Projektionen in der heutigen Historiographie der Kindheit. Neue Sammlung, 25, 450-464.

von Hentig, H. (1977). Erkennen durch Handeln. Zur Rehabilitierung der Erfahrung im Lernen. Die Deutsche Schule, 69(69), 495-515.

Waldenfels, B. (1986). Heimat in der Ferne. In Ders., In den Netzen der Lebenswelt (pp. 194-214). Frankfurt, M.: Suhrkamp.

Wolf, Chr. (1985). Kindheitsmuster. 13.Aufl. Darmstadt, Neuwied: Luchterhand. 